DOI: 10.34015/2523-4552.2019.2.09

УдК 343.823

Кирилюк В. А., кандидат юридичних наук, заступник начальника управління начальник відділу проходження служби та комплектування Управління персоналу Адміністрації Державної кримінально-виконавчої служби України e-mail:valentyna12345@ukr.net

\title{
ОСОБЛИВОСТІ ПРАВОВОГО РЕГУЛЮВАННЯ ДІЯЛЬНОСТІ СВЯЩЕННОСЛУЖИТЕЛІВ (КАПЕЛАНІВ) В УСТАНОВАХ ДЕРЖАВНОЇ КРИМІНАЛЬНО-ВИКОНАВЧОЇ СЛУЖБИ УКРАЇНИ ТА ОРГАНАХ ПРОБАЦІЇ
}

У статті розглядаються окремі питання нормативно-правового регулювання права засуджених на свободу віросповідання в умовах відбування покарання в установах виконання покарань та органах пробації, а також діяльності священнослужителів (капеланів) відповідно до міжнародних нормативно-правових актів та вітчизняного законодавства.

Ключові слова: душпастирська опіка засуджених, установи виконання покарань, органи пробації, священнослужителі (капелани).

В статье рассматриваются некоторые вопросы нормативно-правового регулирования права осужденных на свободу вероисповедания в условиях отбывания наказания в учреждениях исполнения наказания и органах пробации, а также деятельности священнослужителей (капелланов) в соответствии с международными нормативно-правовыми актами и отечественным законодательством.

Ключевые слова: душпастырская опека осужденных, учреждения исполнения наказаний, органы пробации, священнослужители (капелланы).

Постановка проблеми. Конституція України визначає, що засуджені користуються всіма правами людини і громадянина, за виключенням обмежень, визначених законом і встановлених вироком суду. Не $\epsilon$ виключенням і право засуджених на свободу віросповідання, порядок реалізації якого регламентований як міжнародними нормативно-право- вими актами, так і національним законодавством. Цьому праву кореспондує обов'язок адміністрації органів і установ виконання покарань та пробації щодо його забезпечення разом $з$ представниками релігійних організацій. Ураховуючи те, що діяльність органів і установ виконання покарань має здійснюватись у суворій відповідності до чинного законо- 
давства, існує актуальна потреба в ефективному правовому регулюванні діяльності священнослужителів (капеланів) на законодавчому та підзаконному рівнях.

Аналіз досліджень і публікацій. Питання душпастирської опіки засуджених та участі священнослужителів (капеланів) у діяльності установ Державної кримінальновиконавчої служби України досліджувалося такими вченими, як Є. Ю. Бараш, С. І. Здіорук, Н. С. Калашник, М.В.Палій, К.Ю.Пантелей, Ю. Є. Решетніков, П. О. Терлецький, О. М. Гумін, О. Г. Колб та інші. Однак на сьогодні актуальною залишається проблема правового регулювання діяльності священнослужителів (капеланів) в установах Державної кримінально-виконавчої служби України та органах пробації, що потребує подальшого дослідження в умовах реформування державної кримінальновиконавчої служби.

Постановка завдання. Метою цієї статті $\epsilon$ аналіз нормативноправового забезпечення діяльності священнослужителів (капеланів) в установах Державної кримінальновиконавчої служби України й органах пробації та вироблення пропозицій щодо його оптимізації.

Виклад основного матеріалу. Основу нормативно-правового регулювання діяльності священнослужителів (капеланів) в установах Державної кримінально-виконавчої служби України та органах пробації складають міжнародні нормативно-правові акти, закони України та підзаконні нормативно-правові акти.

Серед міжнародних нормативно-правових актів, що регулюють відносини в окресленій сфері, найперше слід звернути увагу на Загальну декларацію прав людини, прийняту Генеральною асамблеєю ООН 10 грудня 1948 р. Так, стаття 18 Декларації визначає що «кожна людина має право на свободу думки, совісті й релігії; це право включає свободу змінювати свою релігію або переконання і свободу сповідувати свою релігію або переконання як одноособово, так і разом з іншими, прилюдним або приватним порядком в ученні, богослужінні і виконанні релігійних та ритуальних обрядів» [1]. Схожа норма міститься і в Міжнародному пакті про громадянські й політичні права, затвердженому Генеральною Асамблеєю ООН 16 грудня 1966 року, стаття 18 якого закріплює, що «кожна людина має право на свободу думки, совісті й релігії. Це право включає свободу мати чи приймати релігію або переконання на свій вибір і свободу сповідувати свою релігію та переконання як одноосібно, так і спільно з іншими, публічно чи приватно, у відповідності до культу, виконанні релігійних i ритуальних обрядів та вчень» [2].

Реалізація цих основоположних засад у сфері виконання покарань і поводження з в'язнями закріплена в Мінімальних стандартних правилах поводження з в'язнями, що містять спеціальний розділ «Релігія», норми якого рекомендують таке: «у закладах, де $\epsilon$ досить велика кількість в'язнів, що належать до однієї конфесії, слід призначати кваліфікованого служителя даного культу або дозволяти йому відправляти там відповідні обряди. Кваліфікований служитель культу, який призначається або допускається в заклад на основі п. 1, повинен мати можливість регулярно проводити релігійні обряди та у відведений для цього час 
періодично відвідувати наодинці в'язнів, які належать до його конфесії, для бесід на релігійні теми. В'язнів не можна позбавляти можливості доступу до кваліфікованих представників будь-якої конфесії» [3].

Європейські пенітенціарні правила також містять спеціальний розділ, присвячений регламентації релігійних потреб ув'язнених - «Свобода думки, совісті та релігії», у якому наголошується на тому, що «треба поважати свободу думки, совісті та релігії ув'язнених. Внутрішній режим, наскільки це можливо, мусить бути організований таким чином, щоб надавати ув'язненим можливість сповідувати свою релігію та віру, відвідувати служби або зібрання, які проводять представники таких релігій або вірувань, які отримали відповідний дозвіл; такі представники релігій або вірувань повинні мати можливість відвідувати ув'язнених і спілкуватися з ними в конфіденційній обстановці; ув'язненим треба дозволяти мати у себе книги та літературу, які стосуються їхньої релігії та вірувань» [4].

Варто зазначити, що наведені положення Загальної декларації прав людини та Міжнародного пакту про громадянські й політичні права відображено в статті 35 Конституції України: «Кожен має право на свободу світогляду і віросповідання. Це право включає свободу сповідувати будь-яку релігію або не сповідувати ніякої, безперешкодно відправляти одноособово чи колективно релігійні культи і ритуальні обряди, вести релігійну діяльність.

Здійснення цього права може бути обмежене законом лише в інтересах охорони громадського порядку, здоров'я і моральності населення або захисту прав і свобод інших людей.

Церква і релігійні організації в Україні відокремлені від держави, а школа - від церкви. Жодна релігія не може бути визнана державою як обов'язкова.

Ніхто не може бути увільнений від своїх обов'язків перед державою або відмовитися від виконання законів за мотивами релігійних переконань» [5].

Норми міжнародних стандартів також імплементовано в Закон України «Про свободу совісті та релігійні організації», який закріплює та гарантує право на свободу совісті громадянам України та здійснення цього права, визначає обов'язки держави та релігійних організацій щодо один одного та суспільства, порядок організації та діяльності релігійних організацій тощо.

Як видається, норми зазначених міжнародних нормативноправових актів відображено й у чинному кримінально-виконавчому законодавстві.

Засуджені користуються всіма правами людини і громадянина, за виключенням обмежень, визначених законом i встановлених вироком суду, тому на них у повному обсязі поширюються норми Конституції України та Закону України «Про свободу совісті та релігійні організації». А от деталізація, конкретизація та обмеження, ураховуючи правовий статус засуджених осіб, визначена нормами кримінально-виконавчого законодавства.

Так, Кримінально-виконавчий кодекс України (далі - КВК) визначає, що релігійні організації можуть надавати допомогу органам та установам виконання покарань у виправленні 
засуджених і проведенні соціальновиховної роботи, а також як одне 3 основних прав засуджених закріплює право на здійснення свободи сповідувати будь-яку релігію або виражати переконання, пов'язані зі ставленням до релігії, у тому числі на вільний вибір i допуск священнослужителя для відправлення релігійних таїнств і обрядів, за винятком обмежень, передбачених цим Кодексом [6].

Душпастирську опіку засуджених в установах виконання покарань закон визначає як діяльність священнослужителів (капеланів), уповноважених релігійними організаціями, статути (положення) яких зареєстровані в установленому законом порядку, яка спрямована на задоволення релігійних потреб засуджених, їх духовне виховання.

Разом $з$ тим заходи душпастирської опіки повинні проводитися таким чином, щоб у жодному разі не порушувати встановлений законом та іншими нормативно-правовими актами порядок виконання і відбування покарань.

Для координації цих заходів центральний орган виконавчої влади, що реалізує державну політику у сфері виконання кримінальних покарань, створює дорадчий орган, до складу якого включаються представники заінтересованих релігійних центрів і управлінь, статути (положення) яких зареєстровані в установленому законом порядку.

Таким дорадчим органом $є$ Душпастирська рада з питань релігійної опіки у пенітенціарній системі України (створена відповідно до наказу Міністерства юстиції України від 05.07.2017 № 2170/5) як постійно діючий міжконфесійний дорадчий орган, що працює на громадських засадах. Завданням Душпастирської ради є координація душпастирської опіки засуджених та осіб, узятих під варту, що перебувають в органах, установах виконання покарань та слідчих ізоляторах Державної кримінально-виконавчої служби України, та персоналу цих органів та установ.

В установах виконання покарань здійснення свободи сповідувати будь-яку релігію або виражати переконання, пов'язані зі ставленням до релігії, підлягає лише тим обмеженням, які необхідні для забезпечення ізоляції, громадської безпеки й установлені КВК.

Богослужіння та релігійні обряди в усіх виправних колоніях можуть проводитися як за проханням засуджених, так і за зверненням релігійної організації в час, вільний від роботи (навчання) засуджених, але 3 відповідними обмеженнями, передбаченими кримінально-виконавчим законодавством України для засуджених різних категорій. Пропаганда будь-яких релігійних учень серед засуджених здійснюється тільки за їх бажанням та згодою, а щодо неповнолітніх - за згодою їхніх батьків або осіб, які їх замінюють. Для відправлення релігійних обрядів та душпастирської опіки засуджених можуть допускатися тільки представники релігійних організацій, які офіційно зареєстровані в установленому законом порядку.

Адміністрація колонії обов'язково надає сприяння в запрошенні священнослужителів, а також визначає місце, час та інші умови проведення богослужіння, обряду або церемонії. У разі відсутності окремих приміщень для віруючих декількох релігійних конфесій обряди проводяться в одному приміщенні за гра- 
фіком. У такому приміщенні передбачається можливість тимчасового розміщення предметів культу на період обряду.

Разом 3 тим адміністрація не має виявляти свого ставлення до певної релігії чи конфесії, але повинна сприяти забезпеченню конфіденційності зустрічей засуджених із священнослужителями (капеланами). Таємниця сповіді $\epsilon$ недоторканною і охороняється законом. Забороняється оприлюднювати, фіксувати технічними засобами та відтворювати будьяку інформацію, отриману зі сповіді. Відомості, отримані зі сповіді, не можуть бути предметом досудового розслідування, досудового слідства чи кримінального провадження, використовуватися як доказ. Ніхто в жодному разі не може допитувати священнослужителя, перекладача чи іншу особу з питань, пов'язаних з конфіденційністю сповіді.

Засуджені можуть придбавати і користуватися релігійною літературою, іншими предметами і матеріалами релігійного призначення, але тільки тими, використання яких не суперечить інтересам забезпечення ізоляції засуджених, а також іншим умовам виконання покарання. Водночас вони не мають права, посилаючись на свої релігійні переконання, ухилятися від виконання своїх обов'язків, а також установлених вимог режиму відбування покарання.

Загалом же відправлення релігійних обрядів не повинно порушувати розпорядок дня в колоніях, а також утискати права інших осіб, які відбувають покарання.

Деякі питання забезпечення релігійних потреб засуджених визначені Правилами внутрішнього розпорядку установ виконання по- карань, затвердженими наказом Miністерства юстиції України від 28.08.2018 № 2823/5. Зокрема, заслуговує на увагу детальний порядок надання дозволу представникам релігійних організацій на відвідування установи виконання покарань.

Для отримання такого дозволу релігійні організації не пізніше ніж за п'ять робочих днів до запланованого відвідування подають до Адміністрації ДКВС, керівництву міжрегіонального управління або установи виконання покарань заяву, у якій зазначають:

повне найменування релігійної організації, місцезнаходження, номер телефону (факсу), електронну пошту; найменування установи виконання покарань, яку планується відвідати (при направленні заяви до Адміністрації ДКВС або міжрегіонального управління);

дату і час відвідування установи виконання покарань;

прізвище, ім'я, по батькові кожного з представників релігійної організації, які планують відвідати установу виконання покарань, серію та номер паспорта, коли і ким виданий.

До заяви додаються копії свідоцтва про державну реєстрацію організації та її статуту.

Крім того, священнослужителі, релігійні проповідники, наставники, інші представники зарубіжних релігійних організацій, які $\epsilon$ іноземними громадянами і тимчасово перебувають в Україні, повинні надати копію офіційного погодження Міністерством культури України можливості зайняття проповідницькою чи іншою канонічною діяльністю та виконання релігійних обрядів.

За результатами розгляду заяви протягом трьох робочих днів Ад- 
міністрація ДКВС (міжрегіональне управління) надає дозвіл на відвідування установи виконання покарань, про що повідомляє заявника.

У разі відсутності в заяві інформації або копій зазначених документів, заявника письмово повідомляють про відмову в наданні дозволу на відвідування установи виконання покарань.

Представники релігійних організацій, які на постійній основі беруть участь у виправленні та ресоціалізації засуджених, проведенні соціально-виховної роботи, можуть відвідувати установи виконання покарань і за спрощеною процедурою.

Для цього зазначеним особам видається перепустка на певний період (місяць, квартал) та на цей період складається графік візитів, який затверджує начальник установи виконання покарань.

Представники релігійних організацій повинні дотримуватися правил поведінки та вимог режиму, установлених в установах виконання покарань. У разі їх порушення за рішенням адміністрації установи виконання покарань відвідування може бути припинено на будь-якій його стадії.

Для задоволення релігійних потреб засуджених та персоналу в усіх установах ДКВС України облаштовано 2583 культові релігійні споруди. Кількість засуджених, які відвідують духовно-просвітницькі заходи, становить 12,4 тис. осіб, що складає близько 22,4 \% від загальної кількості засуджених та осіб, узятих під варту. Духовно-просвітницьку роботу із засудженими проводять представники 55 релігійних конфесій, громад, організацій та церков, офіційно зареєстрованих в Україні [7].
Отже, правові та організаційні засади участі релігійних організацій у виправленні та проведенні соціально-виховної роботи із засудженими в установах виконання покарань чітко визначені в КВК, окремі процедурні питання регламентовані Правилами внутрішнього розпорядку УВП та СІЗО.

Натомість участь релігійних організацій у комплексі заходів соціально-виховного та психологічного супроводу суб'єктів пробації потребує окремого вивчення та правової регламентації.

Положення міжнародних нормативно-правових актів (Рекомендація CM / Rec (2010) 1 Комітету Міністрів державам-членам про правила Ради Європи про пробації та Рекомендація CM / Rec (2017) 3 Комітету міністрів державам-членам щодо європейських правил щодо санкцій та інших заходів) стосуються лише питань недискримінації на підставі релігії як у роботі органів пробації з правопорушниками, так і при відборі персоналу самих органів пробації. Ці міжнародні акти лише визначають необхідність служби пробації працювати у взаємодії з іншими державними або приватними організаціями та місцевими органами самоврядування для того, щоб сприяти залученню засуджених у життя суспільства. До таких організацій можна віднести і релігійні.

Закон України «Про пробацію», прийнятий Верховною Радою України 05 лютого 2015 року, не містить ані визначення душпастирської діяльності у сфері пробації, ані, тим більше, правової регламентації діяльності священнослужителів (капеланів) стосовно суб'єктів пробації. 
Водночас цей законодавчий акт передбачає можливість залучення до роботи служби пробації волонтерів.

Волонтер пробації - фізична особа, яка досягла вісімнадцятирічного віку, уповноважена органом пробації та волонтерською організацією на виконання окремих завдань, пов'язаних із пробацією, на добровільній та безоплатній основі.

Згідно зі статтею 20 Закону України «Про пробацію» волонтерська діяльність, пов'язана з пробаці$€ ю$, здійснюється відповідно до Закону України «Про волонтерську діяльність» 3 урахуванням особливостей, визначених цим Законом. Основним завданням волонтерів пробації $\epsilon$ сприяння органу пробації у здійсненні нагляду за засудженими та проведенні з ними соціальновиховної роботи. Волонтери пробації здійснюють свої повноваження під керівництвом персоналу органу пробації.

Напрями волонтерської діяльності, пов'язаної з пробацією, визначено в Положенні про організацію діяльності волонтерів пробації, затвердженому наказом Міністерства юстиції України 17.01.2017 № 98/5. Серед них, зокрема, такі:

сприяння уповноваженим органам $з$ питань пробації у здійсненні наглядових заходів за місцем роботи та навчання суб'єктів пробації;

участь у проведенні соціальновиховної роботи із суб'єктами пробаціï;

участь у складанні та реалізації індивідуальних планів роботи із суб’єктами пробації;

участь у проведенні індивідуально-профілактичної роботи із суб'єктами пробації; надання консультативної, психологічної та інших видів допомоги суб'єктам пробації;

сприяння у працевлаштуванні суб'єктів пробації, залученні їх до навчання, виховних заходів та соціально корисної діяльності;

сприяння в реалізації пробаційних програм стосовно суб'єктів пробації, звільнених від відбування покарання з випробуванням;

участь у реалізації інших заходів, спрямованих на виправлення суб'єктів пробації та запобігання вчиненню ними повторних кримінальних правопорушень.

Залучення до волонтерської діяльності здійснюється уповноваженим органом $з$ питань пробації за письмовою заявою особи після проходження співбесіди з представником персоналу органу пробації та заповнення анкети.

Під час співбесіди з'ясовується придатність особи до волонтерської діяльності, яка сприятиме здійсненню різних видів пробації, мотивація до цієї діяльності, досвід роботи 3 людьми, освіта та інші відомості, що характеризують кандидата. Кандидатові у волонтери пробації може бути встановлено іспитовий строк до трьох місяців, під час якого вивчаються його моральні та ділові якості, необхідні для виконання окремих завдань пов'язаних з пробацією.

3 волонтером укладається письмовий договір, який містить опис та період здійснення волонтерської діяльності, завдання, які необхідно вирішувати, права та обов'язки сторін, відповідальність за завдання шкоди, умови розірвання договору.

Не може залучатися як волонтер пробації особа, яка має непогашену або незняту судимість, а також 
той, хто раніше був виключений зі складу волонтерів через дії, які негативно вплинули на репутацію, порушили права суб'єктів пробації.

Таким чином, можна погодитися 3 А.Х.Степанюком у тому, що жодних пересторог щодо участі представників релігійних організацій як волонтерів пробації не передбачено, тому якщо релігійна організація виступає і волонтерською організацією, то за погодженням з органом пробації представник цієї організаціє може бути уповноваженим на виконання окремих завдань, пов'язаних із пробацією, на добровільній та безоплатній основі.

Варто також акцентувати увагу на тому, що відповідно до частини третьої статті $128^{1}$ КВК порядок спеціальної підготовки священнослужителів (капеланів) та надання їм повноважень на здійснення заходів душпастирської опіки засуджених погоджується центральним органом виконавчої влади, що реалізує державну політику у сфері виконання кримінальних покарань.

Так, до недавнього часу на виконання окремого доручення ДПтС України від 16.06.2016 № 414-16 відповідно до затвердженої Навчальної програми спеціалізованого курсу навчання священнослужителів (капеланів) Української міжконфесійної християнської місії «Духовна та благодійна опіка в місцях позбавлення волі» таке навчання здійснювалося на базі Інституту кримінальновиконавчої служби. Протягом 20162019 років 320 священнослужителів (капеланів) успішно завершили навчання за цією програмою, що підтверджено відповідними сертифікатами.
Проте розпорядженням Кабінету Міністрів України від 13 березня 2019 року № 145 -р Інститут кримінально-виконавчої служби ліквідовано. Таким чином, на сьогодні та в майбутньому питання забезпечення виконання вимог частини третьої статті $128^{1}$ КВК України та фахової підготовки священнослужителів (капеланів) залишається відкритим, що ставить під загрозу реалізацію мети і завдань кримінальновиконавчого законодавства з огляду на те, що діяльність релігійних організацій у процесі виправлення та ресоціалізації засуджених, без перебільшення, можна визначити рушійною силою, оскільки саме священнослужителі (капелани) мають визначальний вплив на зміну свідомості засуджених.

Висновки. Правове регулювання вітчизняним законодавством свободи віросповідання засуджених в умовах відбування покарання в установах виконання покарань та діяльності священнослужителів (капеланів) відповідає міжнародним нормативно-правовим актам. Участь релігійних організацій у комплексі заходів соціально-виховного та психологічного супроводу суб'єктів пробації потребує окремого вивчення та правової регламентації. Додаткового правового регулювання потребують правовідносини, які виникають за необхідності запрошення священнослужителів (капеланів) 3 ініціативи засуджених, а також у сфері опіки персоналу установ виконання покарань. Тому вважається за доцільне розробити Положення про діяльність священнослужителів (капеланів) в установах виконання покарань та органах пробації. 


\section{Список використаних джерел}

1. Загальна декларація прав людини № 995_015 прийнята Генеральною асамблеєю ООН 10.12.1948 p. URL: http://zakon.rada.gov.ua/laws/show/995_015 (дата звернення: 11.03.2019).

2. Міжнародний пакт про громадянські й політичні права, прийнятий Генеральною Асамблеєю ООН 16 грудня 1966 p. URL: http://zakon.rada.gov.ua/ laws/show/995_043 (дата звернення: 11.03.2019).

3. Мінімальні стандартні правила поводження 3 в'язнями. № 995_212 // 30.08.1955 p. URL: http://zakon.rada.gov.ua/laws/show/995_212 (дата звернення: 11.03.2019).

4. Європейські пенітенціарні правила (рекомендація № R(2006) 2 Комітету Міністрів держав-учасниць), прийняті Комітетом Міністрів 11.01.2006 р. на 952-й зустрічі заступників міністрів. URL: http://zakon.rada.gov.ua/laws/show/995_032 (дата звернення: 14. 03.2019).

5. Конституція України URL: http:// zakon.rada.gov.ua/laws/show/254к/96-вр (дата звернення: 11.03.2019).

6. Кримінально-виконавчий кодекс України URL: http:// zakon.rada.gov.ua/ laws/show/1129-15 (дата звернення: 14. 03.2019).

7. Приклади правового регулювання душпастирського служіння у пенітенціарній системі в країнах Європи : матеріали міжнародної науково-практичної конференції (3 грудня 2018 р., м. Київ) / Упор. Н. В. Пуряєва. Київ, ФОП Кандиба Т.П., 2018. 200 c.

8. Кузь I. Правове регулювання взаємодії органів та установ виконання покарань з релігійними організаціями. Вісник Пенітенціарної асоціації України. 2019. №1. C. 145-153. DOI: 10.34015/2523-4552.2019.1.13

\section{References}

1. Zagalna deklaraciya prav lyudini № 995_015 prijnyata Generalnoyu asambleyeyu OON 10.12.1948 r. URL: http://zakon.rada.gov.ua/laws/show/995_015 (accessed: 11.03.2019) [in Ukrainian].

2. Mizhnarodnij pakt pro gromadyanski j politichni prava, prijnyatij Generalnoyu Asambleyeyu OON 16 grudnya 1966 r. URL: http://zakon.rada.gov.ua/laws/show/995_043 (data zvernennya: 11.03.2019) [in Ukrainian].

3. Minimalni standartni pravila povodzhennya z v'yaznyami. № 995_212 // 30.08.1955 r. URL: http://zakon.rada.gov.ua/laws/show/995_212 (accessed: 11.03.2019) [in Ukrainian].

4. Yevropejski penitenciarni pravila (rekomendaciya № R(2006) 2 Komitetu Ministriv derzhav-uchasnic), prijnyati Komitetom Ministriv 11.01.2006 r. na 952-j zustrichi zastupnikiv ministriv. URL: http://zakon.rada.gov.ua/laws/show/995_032 (accessed: 14. 03.2019) [in Ukrainian].

5. Konstituciya Ukrayini (1996) URL: http:// zakon.rada.gov.ua/laws/show/ 254k/96-vr (accessed: 11.03.2019).

6. Kriminalno-vikonavchij kodeks Ukrayini URL: http:// zakon.rada.gov.ua/ laws/show/1129-15 (accessed: 14. 03.2019) [in Ukrainian].

7. Prikladi pravovogo regulyuvannya dushpastirskogo sluzhinnya u penitenciarnij sistemi $v$ krayinah Yevropi (2018). materiali mizhnarodnoyi naukovo-praktichnoyi konferenciyi (3 grudnya 2018 r., m.Kiyiv). Kiyiv, FOP Kandiba T. [in Ukrainian].

8. Kuz, I. (2019). Legal regulation of the interaction penal institutions with religious organizations. Bulletin of the Penitentiary Association of Ukraine, 1, 145-153. DOI: 10.34015/2523-4552.2019.1.13 [in Ukrainian]. 
V. Kirilyuk, PhD in Law, Deputy Head - Head of service staffing and management personnel Administration of the State Criminal-Executive Service of Ukraine

e-mail: valentyna12345@ukr.net

\section{Features of legal regulation of the activities of chaplains at the establishments of the state criminal-executive service of Ukraine and at the probation bodies}

The article deals with the some issues of the legal regulation of the convicted persons' right of the religion freedom in the conditions of serving a sentence at the penal establishments and probation agencies, as well as the activities of the clergy (chaplains) in accordance with international legal acts and national legislation.

It is stated that the national legislation regulating the freedom of religion of convicts serving sentences at the penal establishments is in accordance with the international legal acts and normative acts, which specify legal relations in that sphere, in particular: organization of carrying out the God worship and other religious rights; the order of receiving the permission by the representatives of the religious organizations to visit the penitentiary institution, etc. Pastoral guardianship of prisoners is carried out by the clerics authorized by the religious organizations, whose statutes are registered according to the current legislation and are aimed at satisfying the religious needs of the convicts and their spiritual education.

The participation of the religious organizations in the complex of measures of social, educational and psychological support of the probation clients requires further research and legal regulation. The norms of the international legal acts in that sphere are related only to the issues of the religious non-discrimination both in the of the probation bodies' activities and in the personnel selection by the probation bodies. International acts only define the need for the probation services to work together with other public or private organizations and local selfgovernance bodies in order to promote the involvement of convicts in the community activities. The Law of Ukraine «On Probation» also does not contain any definition of pastoral activities in the sphere of probation or legal regulation of the activity of clergy (chaplains) in relation to the probation clients. At the same time, the above mentioned legislative act provides the possibility of involving volunteers, in particular representatives of the religious organizations, in the probation activities.

Keywords: pastoral care of convicts; penitentiary institutions; probation bodies; clergy (chaplains).

Надійшла до редакції 03.08.2019 